\title{
Alumina ceramics obtained by chemical synthesis using conventional and microwave sintering
}

\section{(Cerâmicas de alumina obtidas por síntese química e sinterizadas em forno convencional e por microondas)}

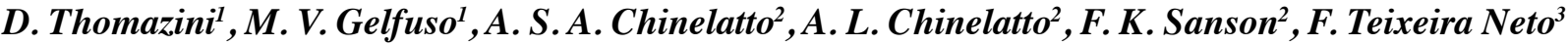 \\ ${ }^{1}$ Itajubá Federal University, Av. BPS 1303, Itajubá, MG, Brazil \\ ${ }^{2}$ Ponta Grossa State University, Av. General Carlos Cavalcanti 4748, Ponta Grossa, PR, Brazil \\ ${ }^{3}$ Fortaleza University, Av. Washington Soares 1321, Fortaleza, CE, Brazil \\ ielthom@gmail.com,mvgelfuso@gmail.com,adriana@uepg.br,adilson@gmail.com,ftnt@gmail.com
}

\begin{abstract}
It is well known that the heating mechanism and powder precursor define the microstructural characteristics of ceramics. Especially abnormal grain growth of pure alumina ceramics developed during conventional sintering method suggests that this material is a potential candidate to be treated in microwave sintering process. Alumina ceramics produced with commercial (A1K) and chemically synthesized powders were sintered in conventional and microwave furnaces. Two methods were employed to prepare the chemically synthesized nanosized powders: Pechini method and emulsification with oleic acid. The microwave sintered samples were characterized by apparent density and scanning electron microscopy and compared with the samples sintered in a conventional furnace. Alumina ceramics sintered in the microwave furnace had fine grained microstructure, not related with the starting powders. This characteristic was achieved in a sintering time shorter than those produced in the conventional furnace. However, satisfactory densification was observed only to A1K ceramics $\left(3.95 \mathrm{~g} / \mathrm{cm}^{3}\right)$ sintered during one hour in microwave furnace.
\end{abstract}

Keywords: synthesis, sintering, microwave, alumina.

\section{Resumo}

É conhecido que os mecanismos de aquecimento e os pós precursores definem as características microestruturais das cerâmicas. Especialmente, o crescimento anormal de cerâmicas de alumina pura desenvolvidos durante o método de sinterização convencional sugere que esse material é um candidato potencial para ser tratado no processo de sinterização em microondas. Cerâmicas de alumina produzidas com pós comercial $(A 1 K)$ e quimicamente sintetizado foram sinterizados em fornos convencional e por microondas. Dois métodos foram empregados para preparar quimicamente os pós nanométricos: método de Pechini e por emulsificação em ácido oleico. As cerâmicas sinterizadas em microondas foram caracterizadas por densidade aparente e por microscopia eletrônica de varredura, e comparados com as amostras sinterizadas em forno convencional. Aluminas sinterizadas em microondas apresentaram uma granulometria fina, não relacionada com os pós precursores. Essa característica foi obtida para um tempo de queima menor do que o obtido em fornos resistivos. Contudo, uma alta densificação foi observada apenas em cerâmicas AlK $\left(3,95 \mathrm{~g} / \mathrm{cm}^{3}\right)$ sinterizadas durante uma hora em microondas.

Palavras-chave: sintese, sinterização, microondas, alumina.

\section{INTRODUCTION}

Microwave sintering $(\mu S)$ is usually described as a process that can promote densification in ceramics at a very high heating rate of about $400{ }^{\circ} \mathrm{C} / \mathrm{min}[1,2]$, at a lower temperature than that employed in the conventional sintering process (cS) [3-6]. High density materials can be obtained by microwave and conventional heating methods [7-9], presenting significant differences in physical properties such as density, mechanical strength and grain size distribution.

Three essential mechanisms of heat transport can act during the conventional heating process: radiation, convection and conduction. In the case of microwave heating, the energy of the electromagnetic radiation is converted directly into thermal energy by reorientation of dipoles in the material. The dielectric loss or loss tangent ( $\left.\tan \delta=\varepsilon^{\prime \prime} / \varepsilon^{\prime}\right)$ indicates the tendency of the material to convert absorbed energy into heat. This type of heating is more efficient, since, unlike heat transport by convection or conduction, it involves no losses. The direct interaction between microwave irradiation and the material causes volumetric heating of the sample, thus eliminating the problem of thermal gradients inherent in conventional firing $[3,10]$.

The structural state of both grain boundaries and surfaces of ultrafine ceramic powders is close to the amorphous state 
[11]. If the influence of reactivity or specific surface area of the materials in a microwave field can be experimentally verified, the effect of grain boundary on the microwave sintering enhancement would be confirmed. Studies involving powders obtained by chemical routes could be very interesting to analyze this propose.

Moreover, the chemical synthesis routes play a crucial role in preparing the final product and are better than traditional methods for the production of fine-grained mixed oxide powders, having good physical properties. Fine powders prepared involve shorter diffusion distances in sintering processes and have improved microstructural homogeneity. Chemically synthesized alumina powders are well known for their nanometric-sized particles and low density ceramics $[12,13]$, which makes them very interesting for microwave sintering. Thus, the aim of this work was to study the sintering behavior of a commercial alumina and alumina chemically synthesized by the Pechini method and by emulsification in oleic acid, using the conventional and microwave sintering processes. The sample densities and microstructures were then compared and analyzed.

\section{EXPERIMENTAL PROCEDURE}

\section{Preparation of alumina powders by chemical synthesis}

Aluminum nitrate salt $\left(\mathrm{Al}\left(\mathrm{NO}_{3}\right)_{3} \cdot 9 \mathrm{H}_{2} \mathrm{O}\right)$ was used for the chemical synthesis of the alumina powders. In the Pechini method (PM), the salt was dissolved in an aqueous solution of citric acid in the proportion of 3:1, under constant agitation and heating. Ethylene glycol was then added in a 40:60 (citric acid: ethylene glycol) ratio, resulting in a PM solution.

For the synthesis with emulsification in oleic acid (OA), aluminum hydroxide was precipitated from the PM solution, using ammonium hydroxide. After filtering the precipitate, oleic acid was added in a ratio of 40:60 to the dry mass of aluminum hydroxide. The precipitate and oleic acid were mixed for $30 \mathrm{~min}$ in a rotary mixer, at a rotation of 800 to $1000 \mathrm{rpm}$, resulting in the OA solution.

The resins obtained by the two methods were calcined at $500{ }^{\circ} \mathrm{C}$ for $1.5 \mathrm{~h}$ and then at temperatures ranging from 900 to $1200{ }^{\circ} \mathrm{C}$. In both cases, the transformation to $\alpha-\mathrm{Al}_{2} \mathrm{O}_{3}$ occurred in the powder treated at $1100^{\circ} \mathrm{C}$ during $120 \mathrm{~min}$, as indicated by the X-ray diffraction (XRD) analysis presented in Figs. 1a and 1b, respectively for OA and PM powders. Fig. 1 shows some spurious peaks related the presence of $\theta$-alumina phase, considered a transition phase, which turns into $\alpha-\mathrm{Al}_{2} \mathrm{O}_{3}$ with increasing calcination temperature. The mean particles sizes, measured by half-width peak in the XRD of the OA and PM calcined powders were $31 \pm 4 \mathrm{~nm}$ and $38 \pm 6 \mathrm{~nm}$, respectively.

The powder density values measured by helium picnometry were 3.68 and $3.96 \mathrm{~g} / \mathrm{cm}^{3}$ for $\mathrm{OA}$ and $\mathrm{PM}$ powders, respectively. The lower density value for $\mathrm{OA}$ powder indicates the presence of $\theta-\mathrm{Al}_{2} \mathrm{O}_{3}$, in agreement with the XRD analysis.
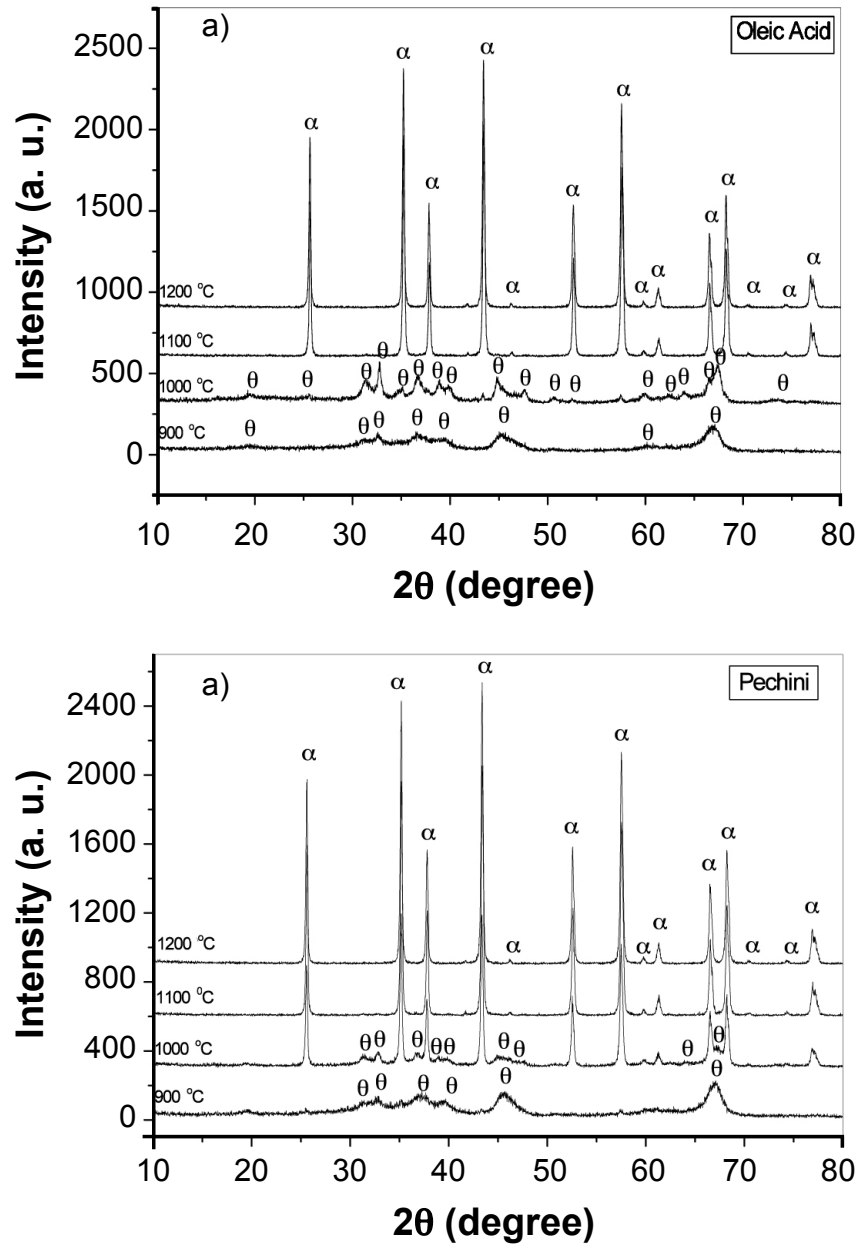

Figure 1: X-ray diffraction patterns of PM alumina powder fired at $900,1000,1100$ and $1200{ }^{\circ} \mathrm{C}$ during $120 \mathrm{~min}$.

[Figura 1: Difratogramas de raios $X$ dos pós de alumina AO e PM calcinados a 900, 1000, 1100 e $1200{ }^{\circ} \mathrm{C}$ durante $\left.120 \mathrm{~min}.\right]$

\section{Ceramics processing and characterization}

The samples were uniaxially pressed under $40 \mathrm{MPa}$ into cylindrical compacts $(9.5 \mathrm{~mm}$ diameter and $3 \mathrm{~mm}$ thickness), after which they were isostatically cold pressed under $150 \mathrm{MPa}$.

The samples obtained by the conventional sintering process, cS ceramics, were sintered in an electrical furnace at $1650{ }^{\circ} \mathrm{C}$ for $5,30,60 \mathrm{~min}$, at $5^{\circ} \mathrm{C} / \mathrm{min}$; on the other hand the $\mu \mathrm{S}$ ceramics were sintered at $1650{ }^{\circ} \mathrm{C}$ at $400{ }^{\circ} \mathrm{C} / \mathrm{min}$ for different times. The microwave furnace used in this work was modified from a domestic model, with a nominal power of $1450 \mathrm{~W}$ and $2.45 \mathrm{GHz}$ operating frequency, $\mathrm{SiC}$ as microwave susceptor and a chamber size of about $8000 \mathrm{~cm}^{3}$. The high-grade $\mathrm{Al}_{2} \mathrm{O}_{3}$ (99.85\% purity, Alcoa ${ }^{\circledR}$ A1000SG), consisting of fine particles averaging $1.05 \pm 0.15$ $\mu \mathrm{m}$ diameter, were used to produced commercial alumina samples (A1K) which were compared with chemical powder ceramics. The particle size of the powder was measured in a particle size distribution equipment (Horiba Capa-700).

The density of the ceramics was determined after 
sintering, based on their mass and geometric dimensions. The microwave effect on densification of alumina was evaluated by the enhancement in the sintered density achieved by microwave and conventional processes.

The fracture surfaces were examined by scanning electron microscopy (SEM, Shimadzu SSX-550) to analyze the grain shape, size distribution and porosity. The grain size of the ceramic bodies was measured with a CAD software.

\section{RESULTS AND DISCUSSION}

Fig. 2 presents the density of A1K, PM and OA ceramics produced by cS method as a function of soaking time. Note that after $2 \mathrm{~h}$ at $1650{ }^{\circ} \mathrm{C}$ the density of the $\mathrm{A} 1 \mathrm{~K}$ samples was about 99.2\% TD. However, the PM and OA samples did not reach density values higher than $76 \% \mathrm{TD}$, probably due to the formation of aggregates, which is very common occurrence in chemically produced powders.

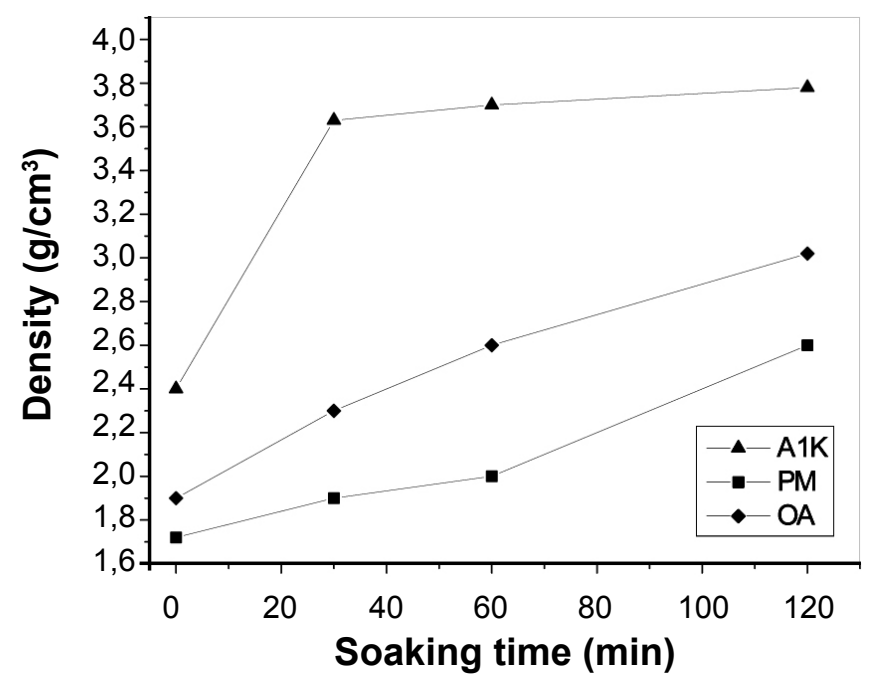

Figure 2: Density as a function of soaking time in conventional firing of PM, OA, and A1K samples.

[Figura 2: Densidade em função do tempo de patamar das amostras $P M, O A$ e AlK sinterizadas em forno convencional.]

Fig. 3 shows the effect of soaking time on the densification of the samples of commercial alumina A1000 $(\mathrm{A} 1 \mathrm{~K})$, Pechini method and emulsification in oleic acid in the $\mu \mathrm{S}$ process. As can be seen, the densification of the commercial alumina samples in the microwave field was higher at the same temperature than that obtained by conventional process. A1K samples presented high densification in $60 \mathrm{~min}\left(3.95 \mathrm{~g} / \mathrm{cm}^{3}\right)$, while the $\mathrm{PM}$ and OA ceramics presented no significant densification. However, their density values were slightly lower than in $\mathrm{PM}$ and $\mathrm{OA} \mathrm{cS}$ samples, suggesting that the densification process is favored in microwave heating. Previous studies [14] showed that ceramics produced with these powders did not present density values exceeding $76 \% \mathrm{TD}$, despite being composed of nanometric particles. These nanometric particles produce aggregates that hinder compaction under pressure and create high porosity. However, an interesting

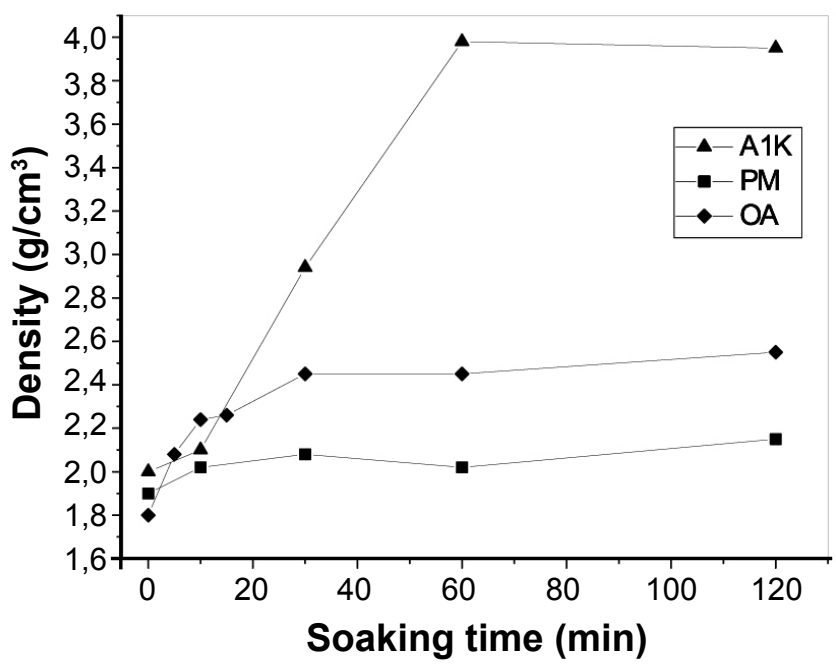

Figure 3: Density as a function of soaking time of microwavesintered ceramics obtained by $\mathrm{PM}, \mathrm{OA}$ and $\mathrm{A} 1 \mathrm{~K}$.

[Figura 3: Densidade em função do tempo de patamar das amostras PM, OA e AIK sinterizadas em forno de microondas.]

finding is that the densities of the $\mathrm{PM}\left(3.0 \mathrm{~g} / \mathrm{cm}^{3}\right)$ and $\mathrm{OA}$ $\left(2.6 \mathrm{~g} / \mathrm{cm}^{3}\right)$ ceramics obtained by the $\mu \mathrm{S}$ and $\mathrm{cS}$ processes were almost the same, although the $\mu \mathrm{S}$ process took less time. In fact, the coupling efficiency of microwaves directly to the material is the primary advantage of microwave processing as compared to traditional routes. The volumetric heating ability of microwaves allows for more rapid and uniform heating, resulting in decreased processing time.

Fig. 4 presents the fracture SEM micrographs of the $\mathrm{A} 1 \mathrm{~K}, \mathrm{PM}$ and $\mathrm{OA}$ ceramics produced by the $\mathrm{cS}$ and $\mu \mathrm{S}$ methods fired at $120 \mathrm{~min}$. Note the more fine-grained microstructure of the $\mu \mathrm{S}$ samples compared to that of the $\mathrm{cS}$ samples, resulting from the faster heating rate applied in microwave sintering, which favors boundary diffusion and grain growth [15]. The grains of the sintered compacts in conventional treatment grow discontinuously, and the grains of the microwave sintered compacts homogeneously.

The lower green density of the $\mu \mathrm{S}$ samples, $32.6 \%$ of TD for the OA ceramics and $43.6 \%$ of TD for the PM ceramics in comparison with A1K ceramics $(\sim 50 \%$ of $\mathrm{TD})$ illustrates the difficulty involved in the conformation of these materials. The low powder compaction can be attributed to the use of nanosized powder (particle size $30 \mathrm{~nm}$ ) and correspondingly smaller pore size in the green body. Critical pore size is achieved at a lower density than in the case of the $\mathrm{A} 1 \mathrm{~K}$ powder with higher particle sizes; thus, the higher values for the green compacts density of A1K previously indicate the higher sintered density for those ceramics.

Cheng et al. [16] found the same dificult when they tryied to densify nanometric alumina particles, achieving green bodies with $\sim 52 \%$ T.D. when sintering nanometric alumina ceramics using microwave energy. The alumina powders were doped with $0.05 \mathrm{wt} . \%$ of $\mathrm{MgO}$ and fired 

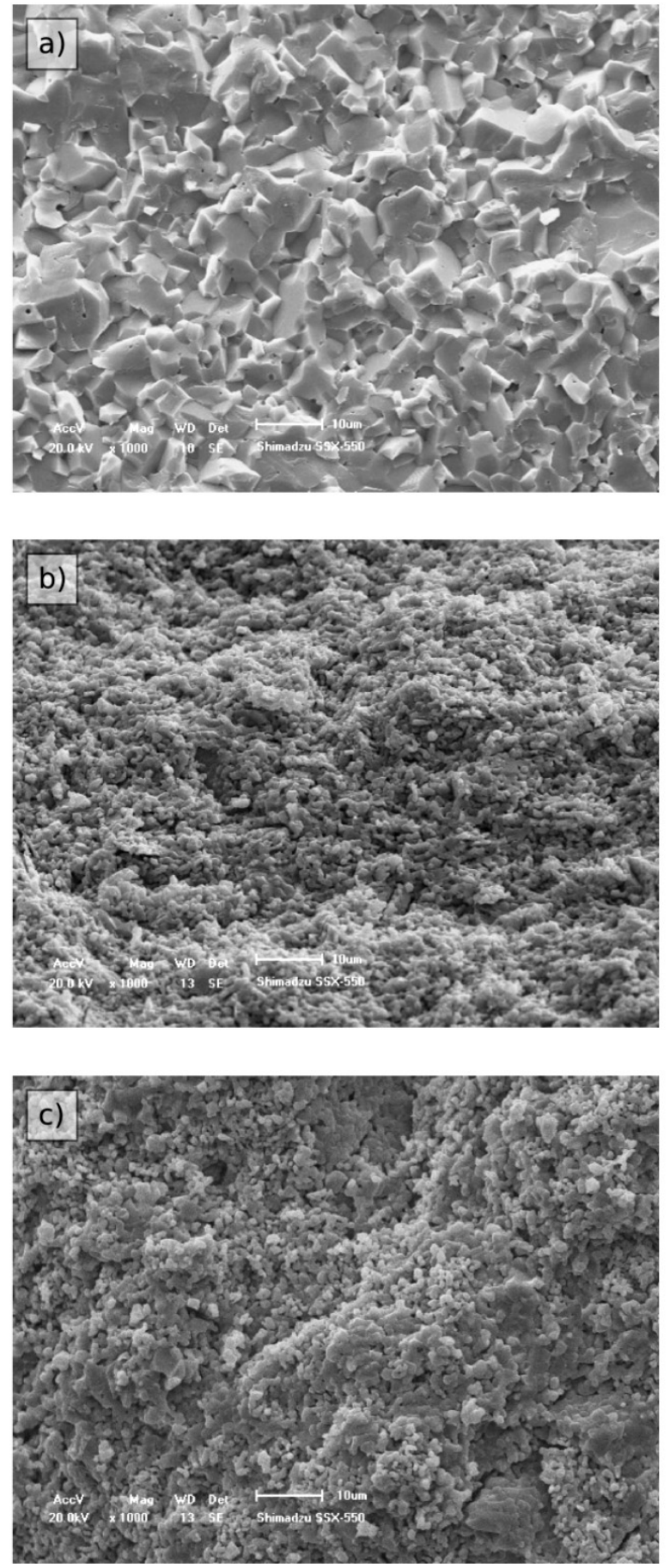
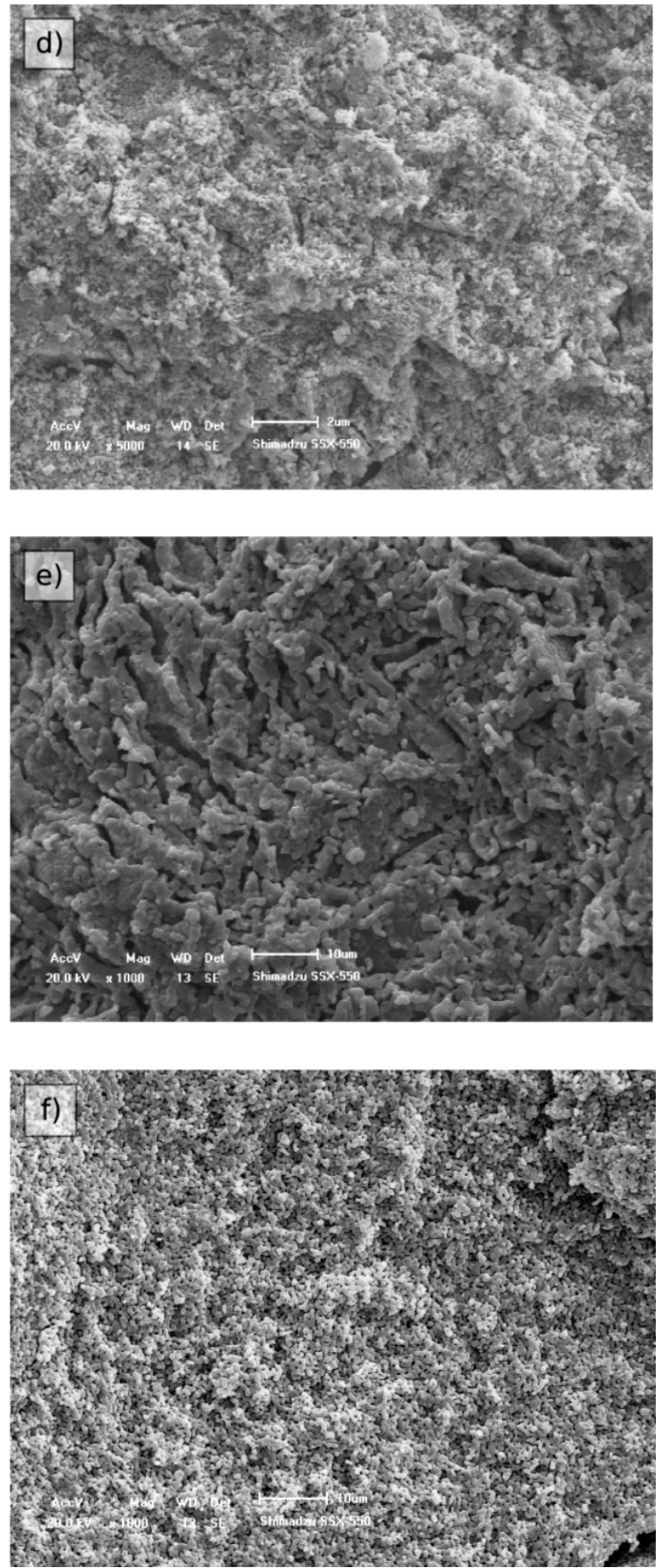

Figure 4: SEM fracture microstructures of (a) AlK-eS, (b) AlK- $\mu \mathrm{S}$, (c) AO-cS, (d) AO- $\mu \mathrm{S}$, (e) PM-cS, and (f) PM- $\mu \mathrm{S}$ ceramics. [Figura 4: MEV das fraturas das cerâmicas (a) AlK-eS, (b) AlK- $\mu S$, (c) AO-cS, (d) AO- $\mu S$, (e) PM-cS, and (f) PM- $\mu S$.]

in $\mathrm{H}_{2}$ atmosphere. These authors demonstrated that the addition of $\mathrm{MgO}$ was fundamental in improving the sintering process of nanometric powders. In addition, Agrawal [10] observed that ceramics with a green density higher than $45 \% \mathrm{TD}$ is more favorable for $\mu \mathrm{S}$ sintering than for $\mathrm{cS}$.

Table I lists the values of the measured grain sizes in the sintered ceramics presented in Fig. 4. As can be seen, the $\mu \mathrm{S}$ values are lower than those of the cS samples. In addition, the final grain size was similar for both ceramics, PM and OA. The control of grain size and grain growth is very important for producing advanced ceramics because abnormal grain growth and grain size influence the characteristics of the ceramic product [17]. Because direct heat transfer in microwave irradiation is more efficient than in conventional irradiation heating, the microwave sintering process was found to occur mainly by grain boundary diffusion, as indicated by the low neck ratios [18], promoting densification without grain growth. Chen and Wang [19] studied two-stage 
Table I - Mean grain size of A1K, PM and OA powders and $\mathrm{cS}$ and $\mu \mathrm{S}$ ceramics.

[Tabela I - Tamanho médio dos grãos para os pós AlK, PM e OA e cerâmicas cS e $\mu S$.]

\begin{tabular}{cccc}
\hline \multicolumn{2}{c}{ Powder } & $\begin{array}{c}\mathrm{cS} \\
(\mu \mathrm{m})\end{array}$ & $\begin{array}{c}\mu \mathrm{S} \\
(\mu \mathrm{m})\end{array}$ \\
\hline $\mathrm{A} 1 \mathrm{~K}$ & $1.05 \pm 0.15$ & $7.51 \pm 2.33$ & $1.14 \pm 0.26$ \\
$\mathrm{PM}$ & $0.038 \pm 0.006$ & $1.16 \pm 0.31$ & $0.56 \pm 0.12$ \\
$\mathrm{OA}$ & $0.031 \pm 0.004$ & $1.19 \pm 0.35$ & $0.55 \pm 0.15$ \\
\hline
\end{tabular}

sintering of alumina with submicrometer grain size and reported the success for densification of a nanometer sized yttria powder without the final stage of grain growth. They postulated that at a certain temperature range (called "kinetic window") densification is already in operation, while the grain boundary motion is not yet activated. The cS samples probably reached this "kinectic window" while PM and OA ceramics did not due to the initial nanosized particle.

\section{CONCLUSIONS}

The samples obtained by microwave sintering presented a finer microstructure than those produced by conventional sintering. This may have resulted from the high heating rate, which favors the sintering process by boundary diffusion. The commercial alumina reaches densification (99.2\% TD) in less time by the microwave sintering process than in the conventional one due to the direct transfer of microwave energy to the samples, which accelerated the densification process. The ceramics produced with chemically synthesized alumina powders did not densify but density values reached results slightly close the ones obtained in the conventional furnace, even being heated for less time. This is due to their low values of green density, which hindered the densification process.

\section{REFERENCES}

[1] D. Thomazini, M. V. Gelfuso, F. Teixeira Neto, Proc. $49^{\circ}$ Cong. Bras. Ceram., Águas de S. Pedro, SP, Brazil (2005).

[2] M. V. Gelfuso, F. Teixeira Neto, D. Thomazini, Cerâmica 53, 327 (2007) 309.

[3] D. D. Upadhyaya, J. Mater. Sci. 36 (2001) 4707.

[4] W. H. Sutton, J. Am. Ceram. Soc. 68 (1989) 376.

[5] D. E. Clarck, W. H. Sutton, Ann. Rev. Mater. Sci. 26 (1996) 299.

[6] R. R. Menezes, P. M. Souto, R. H. G. A. Kiminami, Cerâmica 53, 327 (2007) 218.

[7] C. Saltiel, Z. Fathi, W. H. Sutton, Mechanical Eng. 26 (1995) 102.

[8] A. Birnboim, D. Gershon, J. Calame, A. Birman, Y. Carmel, J. Rodgers, B. Levush, Yu. V. Bykov, A. G. Eremeev, V. V. Holoptsev, V. E. Semenov, D. Dadon, P. L. Martin, M. Rosen, R. Hutcheon, J. Am. Ceram. Soc. 81 (1998) 1493.

[9] M. V. Gelfuso, F. Teixeira Neto, D. Thomazini, Proc. $11^{\text {th }}$ Int. Meeting Ferroelectricity, Iguassu Falls, PR, Brazil (2005).

[10] D. Agrawal, J. Cheng, R. Peelamedu, R. Roy, Current Adv. Mater. Processes 17 (2004) 670.

[11] Y. Fang, J. Cheng, D. Agrawal, Mater. Lett. 58 (2004) 498.

[12] P. Bowen, C. Carry, Powder Technol. 128 (2002) 248.

[13] R. E. P. Salem, A. L. Chinelatto, A. S. A. Chinelatto, Mater. Sci. Forum 591 (2008) 649-653.

[14] A. S. A. Chinelatto, Proc. $50^{\circ}$ Cong. Bras. Ceram., S. Paulo, SP, Brazil (2006).

[15] D. Agrawal, Y. Fang, D. M. Roy, R. Roy, Microwave Proc. Mater. III 269 (1992) 231.

[16] J. Cheng, D. Agrawal, Y. Zhang, R. Roy, Mater. Lett. 56 (2002) 587.

[17] Y. Hotta, T. Banno, S. Sano, A. Tsuzuki, K. Oda, J. Ceram. Soc. Japan 108 (2000) 103.

[18] M. F. Ashby, Acta Metal. 22 (1974) 275.

[19] W. Chen, X. H. Wang, Nature 404 (2000) 168.

(Rec. 17/03/2010, Rev.05/04/2010, Ac.08/05/2010) 